\title{
Perbandingan Asupan Makan Dan Aktifitas Fisik Pada Remaja Berdasarkan Status Gizi
}

\author{
Susmiati ${ }^{a}$, Nur Indrawaty Lipoeto ${ }^{\mathrm{b}}$, Zifrianthi Minanda Putri ${ }^{\mathrm{a}}$ \\ ${ }^{1}$ Fakultas Keperawatan, Universitas Andalas, Kampus Limau Manis, Padang, Sumatra Barat, 25148 \\ ${ }^{2}$ Fakultas Kedokteran, Universitas Andalas, Kampus Jati, Padang, Sumatra Barat, 25148 \\ Email korespondensi : susmiati@nrs.unand.ac.id
}

\begin{abstract}
To date, the cause of obesity is unclear and debatable. Effective treatment and prevention of obesity is achievable if its pathogenesis is known comprehensively. The objective of this research is to study and compare dietary intake and physical activities among adolescents between obese and normal ones. The study is conducted by case-control with 311 samples of female adolescents. Sampling was conducted by stratified random sampling. Obesity criterion was based on BMI > $2 S D$ and normal -2 SD $\langle B M I>1 S D$. Dietary patterns was determined using semiquantitative Food Frequency Questionnaire (FFQ) and physical activity was determined by Physical Activity Questionnaire for Older Children (PAQC). Average total energy intake on the obese was 2344,92 506,31 kcal/day, higher than that of the normal group $(2285,41 \pm 602,86$ kcal/day), but there was no significant difference between the two groups $(p=0.435)$. Among subjects with mild physical activities, $62.9 \%$ were obese, whereas $58.9 \%$ were in normal group. There was no significant relationship between physical activities and obesity $(p=0.27)$. Average intake of carbohydrates, protein, fat, fiber, and fatty acid is higher on those with high physical activities than those with moderate and low physical activities. There was a significant relationship between dietary intake and physical activities with $p<0.05$. In conclusion, there was no difference between dietary intake and physical activities based on nutritional status on adolescents.
\end{abstract}

Keywords : dietary intake, physical activity, adolescents and obesity

\begin{abstract}
Abstrak
Penyebab obesitas sampai sekarang masih belum jelas dan masih diperdebatkan. Pengobatan dan pencegahan obesitas yang efektif dapat dicapai jika diketahui patogenesis secara komprehensif. Tujuan penelitian ini adalah untuk mengkaji perbandingan asupan makan dan aktifitas fisik pada remaja dengan obesitas dan normal. Penelitian dilakukan secara case control dengan sampel sebanyak 311 remaja putri. Pengambilan sampel dilakukan secara stratified random sampling. Kriteria obesitas berdasarkan IMT $>2$ SD dan Normal -2 SD <IMT> 1 SD. Pola makan ditentukan dengan semi-kuantitatif Food Frequency Quessioner (FFQ) dan aktifitas fisik dengan Physical Activity Questionnaire for Older Children (PAQC). Rata- rata asupan energi total kelompok obes $2344,92 \pm 606,31 \mathrm{kcal} /$ hari lebih tinggi dari kelompok normal $2285,41 \pm 602,86 \mathrm{kcal} / \mathrm{hari}$, tapi tidak ada perbedaan yang bermakna antar kedua kelompok $\mathrm{p}=0,435$. Subyek dengan tingkat aktifitas fisik ringan 62,9\% mengalami obesitas sementara 58,9\% termasuk kelompok normal. Tidak ada hubungan yang bermakna tingkat aktifitas fisik dengan obesitas $\mathrm{p}=0,27$. Rata-rata asupan karbohidrat, protein, lemak, serat dan asam lemak lebih tinggi pada aktifitas tinggi dibandingkan tingkat aktifitas sedang dan rendah. Ada perbedaan yang bermakna antara asupan makanan dengan tingkat aktifitas fisik $\mathrm{p}<0,05$. Kesimpulan tidak ada perbedaan antara asuan makan dan aktifitas fisik berdasarkan status gizi pada remaja.
\end{abstract}

Kata Kunci : pola makan, aktifitas fisik, remaja dan obesitas 


\section{PENDAHULUAN}

menjadi $\begin{gathered}\text { Obesitas menjadi masalah global dan } \\ \text { perhatian bagi dunia }\end{gathered}$ kesehatan. Prevalensi obesitas di negara maju serta negara berkembang terus meningkat, walaupun berbagai metode pencegahan obesitas telah dilakukan melalui perubahan gaya hidup berupa pengaturan polamakandan aktifitasfisik. Pengobatan dan pencegahan obesitas ini belum dapat dicapai karena etiologi dan patogenesis obesitas sampaisekarangmasihbelumjelas dan masih diperdebatkan.

Obesitas merupakan resiko kelima penyebab kematian di dunia yang dapat dicegah dengan berbagai cara. Pada tahun 2016 39\% remaja umur 18 tahun/ lebih termasuk kategori gemuk dan $13 \%$ obese.Sekitar 340juta anak dan remaja umur 5-19 tahun adalah gemuk dan sangat gemuk (WHO, 2016). Pada populasi remaja usia 517 tahun, $70 \%$ remaja obesitas terancam penyakit kardiovaskular (Freedman et al, 2007), kadar glukosa darah tinggi yang menunjukkan resiko tinggi untuk berkembang menjadi diabetes dan resiko masalah tulang dan sendi, sleep apnea, dan masalah-masalah sosial dan psikologis seperti stigmatisasi dan harga diri rendah.

Prevalensi kelebihan berat badan dan obesitas juga meningkat pada anak-anak dan remaja di negara berkembang, dari $8,1 \%(7,7-8,6)$ sampai 12,9\% (12,3-13,5) di tahun 2013 untuk anak laki-laki dan dari $8,4 \%(8,1-8,8)$ sampai $13,4 \%(13,0-13,9)$ pada anak perempuan $(\mathrm{NgM}$, Fleming et al., 2014). Kelompok remaja perempuan merupakan kelompok prioritas dalam mencegah obesitas, karena pada remaja dampak obesitas bukan hanya pada remaja itu sendiri tapi juga pada turunannya. Penurunan kecenderungan obesitas pada remaja perempuan harus terus dikembangkan untuk perbaikan kualitas kesehatan janin sebagai generasi masa depan(Todd et al., 2015). Identifikasi factor resiko pada remaja merupakan cara paling tepat untuk intervensi obesitas dan menurunkan resiko kardiovaskuler.

Penyebab obesitas sampai sekarang masih belum jelas dan masih diperdebatkan.Pengobatan dan pencegahan obesitas yang efektif dapat dicapai jika diketahui patogenesis secara komprehensif.Prevalensi obesitas pada remaja umur 13-15 tahun di Sumatera Barat yang mayoritas etnis Minangkabau hampir sama dengan prevalensi nasional yaitu sebesar $10.8 \%$, terdiri dari $8,3 \%$ gemuk dan 2,5\% sangat gemuk (obesitas)( Riskesdas, 2013). Sementara studi terdahulu melaporkan bahwa etnis Minangkabau memiliki pola diet yang berbeda dengan etnis lainnya di Indonesia dengan rata-rata asupan energi lebih rendah $(72,4 \%)$ dari Angka Kecukupan Gizi (AKG) Nasional 2150 kkal). Berdasarkan rasio PUFA: MUFA: SAFA, etnis Minangkabau memiliki kualitas pola diet lemak yang buruk dan asupan lemak yang lebih tinggi dibandingkan dengan kelompok etnis lainnya(Hatma, 2001). Pada umumnya makanan terdiri dari nasi, ikan, kelapa, sayur hijau dan cabe, dimana sedikit sekali variasi antara makan siang, malam dan sarapan (Lipoeto et al., 2001).

Peningkatan asupan makanan dan penurunan aktivitas fisik dulu sering dianggap sebagai penyebab obesitas, tetapi tidak semua orang yang mengkonsumsi lebih banyak energi, bertambah berat badannya dan tidak semua orang menjadi gemuk ketika tinggal di lingkungan yang sama. Beberapa individu bisa menaikkan atau menekan berat badan lebih mudah dari yang lain.Individu yang lebih berespon dengan perubahan diet tertentu sangat penting untuk intervensi dalam pengobatan obesitas, karena dapat dilakukan penyesuaian desain manajemen berat badan dan bimbingan diet pada individu. Pengobatan dan pencegahan obesitas yang efektif dapat dicapai jika diketahui patogenesis secara komprehensif. Sejauh ini banyak studi tentang faktor yang mempengaruhi kejadian obesitas, tapi kajian yang mendalam mengenai interaksi pola makan dan aktifitas fisik pada remaja terhadap kejadian obesitas masih terus berkembang.. Berdasarkan alasan diatas maka perlu diteliti bagaimana perbandingan asupan makan dan aktifitas fisik pada remaja obesitas.

\section{METODE}

Penelitian ini merupakan penelitian dengan desain studi kasus kontrol untuk pola makan dan aktifitas fisik pada remaja obesitas.

Populasi penelitian adalah siswa perempuan sekolah menengah pertama (SMP) yang berada di 4 kabupaten/kota di Sumatera 
Barat. Subyek penelitian dipilih secara proporsional random sampling yaitu remaja perempuan yang memenuhi kriteria inklusi dan eklusi dimasukkan dalam subyek penelitian. Jumlah kasus dan kontrol sama di setiap sekolah berdasarkan proporsi obesitas masing-masing sekolah.

Kelompok kontrol diambil dari siswi sekolah yang sama yang mempunyai IMT Z score antara -2 SD sampai +1 SD dan kelompok kasus IMT Z score diatas +2 SD standar WHO. Dengan menggunakan rumus diatas maka didapatkan jumlah subyek penelitian untuk kelompok kasus 143 orang dan kelompok kontrol 168 orang. Total subyek ( kasus dan kontrol) yang dibutuhkan adalah sebanyak 311 orang.

Indeks Massa Tubuh (IMT) atau Body Mass Index (BMI) dihitung berdasarkan pemeriksaan antropometriberat badan $(\mathrm{kg})$ dibagi kuadrat tinggi badan $\left(\mathrm{m}^{2}\right)$. Obesitas jika BMI $\mathrm{Z}$ score > + SD dan non-obesitas jika BMI Z score > -2 SD - <+1SD (WHO 2007 growth reference).

Pola Makan dinilai menggunakan semikuantitatif Food Frequency Quessioner (FFQ) dengan 136 item makanan. Quessionnaire ini telah divalidasi pada populasi yang sama. Asupan Nutriens termasuk energi (kkal / hari, total lemak (g/hari), SFA (g / hari), MUFA (g/ hari), protein (g/hari), karbohidrat (g/ hari), dan serat (g/ hari).

Aktivitas fisik didefinisikan sebagai jenis dan frekuensi olahraga dan / atau menari remaja yang dilakukan selama 7 hari terakhir dan menilai kegiatan remaja selama pendidikan jasmani (olah raga) kelas, istirahat, waktu makan siang, setelah sekolah, malam hari, akhir pekan dan waktu luang. Aktifitas fisik diukur dengan self report questionaire Physical Activity Questionnaire for Older Children (PAQC). Aktifitas fisik rendah score $\langle 2.33$, sedang 2.33-3.66 and tinggi/aktif $>$ 3.66. ${ }^{(8)}$.

Analisis data digunakan untuk melihat distribusi data masing-masing variabel dan kemudian disajikan dalam bentuk tabel atau diagram. Data terdiri dariukuran antropometri (obes atau non obese, IMT, lingkar pinggang, lingkar panggul, rasio lipi/lipa, persen lemak tubuh), asupan makan dan aktifitas fisik. Kolmogorof-Smirnov digunakan untuk menentukan distribusi data.Perbedaan antropometri, asupan makanan,aktifitas fisik antara obesitas dan non obese dengan uji t test ( data terdistribusi normal) atau Mann-Whitney U ( data terdistribusi tidak normal) test ), sedangkan perbedaan asupan makan berdasarkan tingkat aktifitas fisik dengan uji annova dengan tinkat signifikan $\mathrm{p}<0,05$.

\section{HASIL}

Penelitian ini dilakukan pada siswi SMP di 4 (empat) Kabupaten /Kota di Sumatera Barat yaitu Kota Padang, Kota Padang Panjang, Kabupaten Padang Pariaman dan Kabupaten Tanah Datar. Subyek penelitian diambil secara stratified random sampling dan dibagi dua kelompok yaitu kelompok obesitas (143 orang) dan normal (168 orang). Hasil penelitian mendapatkan rerata umur kelompok obes 13,57 $\pm 1,05$ tahun lebih rendah dibandingkan dengan kelompok normal 13,88 $\pm 0,89$ tahun. Ada perbedaan umur yang yang signifikan antara kelompok obes dan normal $\mathrm{p}=0,005$.

Tabel 1. Karakteristik Subjek berdasarkan antropometri

\begin{tabular}{llll}
\hline \multicolumn{1}{c}{ Antropometri } & \multicolumn{1}{c}{ Obesitas } & \multicolumn{1}{c}{ Normal } & $P$ \\
\hline Tinggi (m) & $1,52 \pm 0,05$ & $1,51 \pm 0,057$ & 0,172 \\
$\begin{array}{l}\text { Berat badan (kg) } \\
\text { Indek Massa }\end{array}$ & $28,58 \pm 10,76$ & $47,9 \pm 7,191$ & $\mathbf{0 , 0 0 0} *$ \\
$\begin{array}{l}\text { Tubuh }\left(\mathrm{kg} / \mathrm{m}^{2}\right) \\
\text { Lingkar }\end{array}$ & $84,6 \pm 6,662$ & $69,81 \pm 2,64$ & $\mathbf{0 , 0 0 0 *}$ \\
pinggang (cm) & & & \\
$\begin{array}{l}\text { Lingkar panggul } \\
\text { (cm) }\end{array}$ & $100,09 \pm 6,67$ & $85,94 \pm 5,82$ & $\mathbf{0 , 0 0 0 *}$ \\
$\begin{array}{l}\text { Rasio Lipi/Lipa } \\
\text { Tekanan darah }\end{array}$ & $0,84 \pm 0,048$ & $0,81 \pm 0,14$ & $\mathbf{0 , 0 0 0 *}$ \\
$\begin{array}{l}\text { Sistolik (mmHg) } \\
\text { Tekanan darah }\end{array}$ & $77,94 \pm 10,683 \pm 12,96$ & $117,89 \pm$ & $\mathbf{0 , 0 0 0 *}$ \\
$\begin{array}{l}\text { Diastolik } \\
\text { (mmHg) }\end{array}$ & & 9,516 & \\
\% Lemak tubuh & $30,79 \pm 1,876 \pm 8,085$ & $\mathbf{0 , 0 0 0 *}$ \\
& & $24,27 \pm 3,165$ & $\mathbf{0 , 0 0 0 *}$ \\
\hline
\end{tabular}

Kelompok obesitas mempunyai rata-rata IMT $28,89 \pm 2,84 \mathrm{~kg} / \mathrm{m}^{2}$ sedangkan kelompok normal mempunyai rata-rata IMT 20,81 $\pm 2,64$ $\mathrm{kg} / \mathrm{m}^{2}$. Ada perbedaan yang bermakna antara IMT kelompok obes dan normal $\mathrm{p}=0,000$. Tidak ada perbedaan tinggi badan yang bermakna antara kelompok obes dan normal $p>0,05$. Ada perbedaan yang bermakna berat badan, lingkar pinggang, lingkar panggul, ratio lingkar pinggang panggul, persen lemak tubuh serta tekanan sistolik dan diastolic antara kelompok obes dan normal $\mathrm{p}<0,05$

Table 2. Perbedaan Asupan makanan antara obesitas dan normal

\begin{tabular}{lcccc}
\hline $\begin{array}{l}\text { Asupan } \\
\text { Makanan }\end{array}$ & \multicolumn{1}{c}{ Obesitas } & Normal & $\mathrm{p}$ \\
\hline Energi & total & $2344,92 \pm$ & $2285,41 \pm 602,86$ & 0,435 \\
$(\mathrm{kcal} / \mathrm{d})$ & & 606,31 & & \\
\hline
\end{tabular}




\begin{tabular}{lcll} 
Karbohidat $(\mathrm{g} / \mathrm{h})$ & $274,75 \pm 71,23$ & $266,73 \pm 72,78$ & 0,377 \\
Karbohidrat $(\% \mathrm{E})$ & $47,23 \pm 7,15$ & $47,04 \pm 6,34$ & 0,827 \\
Lemak $(\mathrm{g} / \mathrm{h})$ & $114,79 \pm 40,64$ & $110,70 \pm 36,94$ & 0,403 \\
Lemak $(\% \mathrm{E})$ & $33,25 \pm 4,57$ & $33,83 \pm 4,70$ & 0,316 \\
Protein $(\mathrm{g} / \mathrm{h})$ & $87,69 \pm 29,45$ & $86,33 \pm 27,37$ & 0,705 \\
Protein $(\% \mathrm{E})$ & $19,58 \pm 3,11$ & $19,27 \pm 3,11$ & 0,461 \\
Serat $(\mathrm{g} / \mathrm{h})$ & $12,04 \pm 5,79$ & $11,52 \pm 5,19$ & 0,453 \\
Saturated fat $(\mathrm{g})$ & $33,56 \pm 13,15$ & $31,98 \pm 11,25$ & 0,309 \\
$\begin{array}{l}\text { Monounsaturated } \\
\text { fat }(\mathrm{g})\end{array}$ & $12,08 \pm 5,63$ & $12,39 \pm 5,02$ & 0,646 \\
Poliunsaturated & $10,17 \pm 4,49$ & $10,00 \pm 4,11$ & 0,766 \\
fat $(\mathrm{g})$ & & & \\
\hline
\end{tabular}

Rata- rata asupan energi total kelompok obes $2344,92 \pm 606,31 \mathrm{kcal} / \mathrm{hari}$ lebih tinggi dari kelompok normal 2285,41 $\pm 602,86 \mathrm{kcal} / \mathrm{hari}$, tapi tidak ada perbedaan yang bermakna antar kedua kelompok $\mathrm{p}=0,435$. Rata-rata asupan karbohidrat $(\% \mathrm{E})$ tergolong kategori rendah dengan asupan $47,23 \pm 7,15 \%$ pada obes dan $47,04 \pm 6,34 \%$ pada normal. Rata-rata asupan lemak $(\% \mathrm{E})$ tergolong tinggi dengan $33,25 \pm 4,57 \%$ pada kelompok obes dan $33,83 \pm 4,70 \%$ pada kelompok normal . Tingkat asupan protein tergolong normal dengan rata-rata asupan $19,58 \pm 3,11 \%$ pada kelompok obes dan $19,27 \pm 3,11 \%$ pada kelompok normal. Asupan serat tergolong normal dengan rata-rata asupan pada obese $12,08 \pm 5,63 \mathrm{~g} /$ hari lebih tinggi dari kelompok normal 11,52 \pm 5,19 g/hari. Berdasarkan asupan asam lemak didapatkan asupan saturated fatty acid (SFA)/lemak jenuh lebih tinggi pada kelompok obes 33,56 $\pm 13,15$ dan kelompok normal $31,98 \pm 11,25$, tetapi secara statistik tidak ada perbedaan yang bermakna $\mathrm{p}=$ 0,309. Asupan monounsaturated fatty acid (MUFA) dan poliunsaterated Fatty acid (PUFA) hampir sama pada kedua kelompok $\mathrm{p}>0,05$.

Tabel 3. Hubungan aktifitas fisik dengan obesitas

$\begin{array}{ll}\begin{array}{l}\text { Obesitas } \\ (n=143)\end{array} & \begin{array}{l}\text { Normal } \\ (n=168)\end{array}\end{array} \quad X^{2}$

\begin{tabular}{clll}
\hline Aktifitas fisik & & & \\
Ringan & $90(62,9 \%)$ & $99(58,9 \%)$ & 0,273 \\
Sedang & $53(37,1 \%)$ & $68(41,1, \%)$ & \\
Tinggi & $0(0 \%)$ & $1(0.01 \%)$ & \\
\hline
\end{tabular}

Subyek dengan tingkat aktifitas fisik ringan $62,9 \%$ mengalami obesitas sementara $58,9 \%$ termasuk kelompok normal. Dari 143 orang yang obesitas $62,9 \%$ dengan tingkat aktifitas fisik ringan dan $37,1 \%$ dengan tingkat aktifitas fisik sedang serta tidak ada satupun dengan tingkat aktifitas tinggi. Tidak ada hubungan yang bermakna tingkat aktifitas fisik dengan obesitas $\mathrm{p}=0,27$.

Tabel 4. Pola makan berdasarkan Aktifitas fisik

\begin{tabular}{|c|c|c|c|c|}
\hline & \multicolumn{3}{|l|}{ Aktifitas fisik } & \multirow{2}{*}{$\begin{array}{l}\mathbf{P} \\
\text { value }^{1}\end{array}$} \\
\hline & $\begin{array}{l}\text { Ringan } \\
(n=187)\end{array}$ & $\begin{array}{l}\text { Sedang } \\
(n=121)\end{array}$ & $\begin{array}{c}\text { Tinggi } \\
(n=1)\end{array}$ & \\
\hline $\begin{array}{l}\text { Energi total } \\
(\mathrm{kkal} / \mathrm{h})\end{array}$ & $\begin{array}{l}2219,24 \\
\pm 594,71\end{array}$ & $\begin{array}{l}2481,60 \pm \\
580,29\end{array}$ & 4080,89 & 0,001* \\
\hline $\begin{array}{l}\text { Karbohidrat } \\
\text { (g) }\end{array}$ & $\begin{array}{l}260,65 \pm \\
70,19\end{array}$ & $288,04 \pm 72,66$ & 301,24 & $0,003 *$ \\
\hline Lemak (g) & $108,41 \pm$ & $120,34 \pm 39,93$ & 274,14 & $0,010 *$ \\
\hline Protein (g) & $82,58 \pm 27,61$ & $94,30 \pm 27,45$ & 209,94 & 0,001* \\
\hline Serat (g & $10,18 \pm 4,42$ & $13,83 \pm 5,46$ & & $0,001 *$ \\
\hline
\end{tabular}

Rata-rata jumlah asupan energi total pada subyek dengan tingkat aktifitas tinggi 4080,89 $\mathrm{kkal} / \mathrm{hari}$ lebih tinggi dari asupan subyek dengan tingkat aktifitas sedang $2481,60 \pm 580,29 \mathrm{kkal} / \mathrm{hari}$ dan subyek dengan tingkat aktifitas rendah $2219,24 \pm 594,71$ kkal/hari. Rata-rata asupan karbohidrat, protein, lemak, serat dan asam lemak lebih tinggi pada aktifitas tinggi dibandingkan tingkat aktifitas sedang dan rendah. Ada perbedaan yang bermakna antara asupan energi total, karbohidrat, protein, serat, lemak dan asam lemak dengan tingkat aktifitas fisik $\mathrm{p}<0,05$.

\section{PEMBAHASAN}

Tidak ada perbedaan yang bermakna asupan makan antara obes dan normal. Hal ini berbeda dengan yang didapatkan pada remaja Saudi arabia (Al-Kutbe, et al., 2017). Penelitian pada mahasiswa di Padang juga mendapatkan tidak ditemukan adanya hubungan rata-rata asupan zat gizi (energi, protein, lemak dan karbohidrat) dengan status gizi (Elnovriza et al.,, 2009). Sedangkan penelitian pada anak sekolah dasar didapatkan hubungan antara asupan energi dan aktivitas fisik dengan kejadian gizi lebih (Nyoman, 2016). Penelitian pada anak sekolah umur 15- 17 tahun menunjukkan ada perbedaan 
yang bermakna tingkat konsumsi energi, karbohidrat, protein, dan lemak, antara kelompok obesitas dan kelompok non obesitas (Suryaputra 2012 dalam Nadia, 2015).

Rata-rata jumlah asupan energi total pada subyek dengan tingkat aktifitas tinggi 4080,89 $\mathrm{kkal} / \mathrm{hari}$ lebih tinggi dari asupan subyek dengan tingkat aktifitas sedang 2481,60 $\pm 580,29 \mathrm{kkal} / \mathrm{hari}$ dan subyek dengan tingkat aktifitas rendah $2219,24 \pm 594,71 \mathrm{kkal} / \mathrm{hari}$. Rata-rata asupan karbohidrat, protein, lemak, serat dan asam lemak lebih tinggi pada aktifitas tinggi dibandingkan tingkat aktifitas sedang dan rendah. Asupan makan sangat dipengaruhi oleh berbagai faktor seperti sosioekonomi, diet, faktor individu dan sosial serta aktifitas fisik(Jodhun BM, 2016). Penelitian lain juga mendapatkan adanya hubungan antara pola sedentary ( banyak menghabiskan waktu untuk menonton dan main komputer) dengan kebiasaan makan yang jelek pada remaja (Pearson 2011 dalam Tsujiguchi 2018).

Pada penelitian ini didapatkan perbedaan yang signifikan antara asupan energy total, karbohidrat, protein, serat, lemak dan asam lemak dengan tingkat aktifitas fisik $\mathrm{p}<0,05$. Hal inilah yang menyebabkan tidak adanya hubungan antara jumlah asupan makanan dan tingkat aktifitas fisk dengan kejadian obesitas pada remaja. Tingginya asupan makan terjadi pada remaja dengan aktifitas tinggi begitu juga sebaliknya. Mekanisme apakah asupan makan yang tinggi menyebabkan remaja bisa beraktifitas yang tinggi atau aktifitas tinggi yang meningkatkan asupan makan, dalam penelitian ini belum bisa dijelaskan karena waktu pengambilan asupan makan dan aktifitas fisik dilakukan secara bersamaan.

\section{KESIMPULAN}

Tidak ada perbedaan yang bermakna pola makan antara obes dan normal pada remaja. Tidak ada hubungan yang bermakna tingkat aktifitas fisik dengan kejadian obesitas pada remaja. Remaja dengan tingkat aktifitas fisik yang tinggi mempunyai asupan makan yang tinggi, sebaliknya remaja dengan tingkat aktifitas fisik yang rendah mempunyai asupan makan yang rendah. Pembatasan asupan makan/pola diet untuk menurunkan berat badan pada remaja harus dilakukan secara hati-hati karna berdampak pada penurunan aktifitas fisik dan terhadap pertumbuhannya.

\section{UCAPAN TERIMA KASIH}

Ucapan terimakasih diucapkan kepada Danone Institute Indonesia dan Dana Dipa Fakultas Keperawatan Unand yang telah memberikan bantuan penelitian. Tak lupa terhadap semua responden yang berpartisipasi dalam penelitian ini.

\section{DAFTAR PUSTAKA}

Al-Kutbe $\mathrm{R}^{1}$, Payne $\mathrm{A}^{2}$, de Looy A et al.,2017. A comparison of nutritional intake and daily physical activity of girls aged 8-11 years old in Makkah, Saudi Arabia according to weight status. BMC Public Health. 2017 Jun 21;17(1):592. doi: 10.1186/s12889-017-4506-2

Dan SP, Mohd NM, Zalilah MS, 2011. Determination of factors associated with physical activity levels among adolescents attending school in Kuantan, Malaysia. Malays J Nutr, 17(2), 175187.

Elnovriza, Deni; Bachtiar, Hafni ; Yenrina, Yenrina. 2009. Hubungan pengetahuan dan asupan zat gizi mahasiswa di Asrama Universitas Andalas. Jurnal Kesehatan Masyarakat Andalas Vol 4, No 1 (2009): Jurnal Kesehatan Masyarakat Andalas page. 21-26

Freedman DS, Mei Z, Srinivasan SR, Berenson GS, Dietz WH, 2007. Cardiovascular risk factors and excess adiposity among overweight children and adolescents: the Bogalusa Heart Study. J Pediatr, 150(1), 12-17 e12

Hatma RD, 2001. Nutient Intake Patterns and Their Relations To lipid Profiles In Diverse Ethnic Populations. Jakarta. P 54, 68, 69, 77.

Jodhun BM, , Jeewon R.2016. A systematic review of factors affecting energy intake of adolescent girls. Afr Health Sci. 2016 Dec;16(4):910-922. doi: 10.4314/ahs.v16i4.5. 
Lipoeto NI, Agus Z, Oenzil F, ML Wahlqwvist, et $\mathrm{al}, 2001$. Contemporary Minangkabau food culture in West Sumatera, Indonesia. Asia Pasific Journal of Clinical Nutrition; 10: 10-6.

Nadia Loliana, Siti Rahayu Nadhiroh. 2015. Asupan dan kecukupan gizi antara remaja obesitas dengan non obesitas. Media Gizi Indonesia, Vol. 10, No. 2 Juli-Desember 2015: hlm. 141-145

$\mathrm{NgM}$, Fleming T, Robinson M, et al., 2014. Global, regional, and national prevalence of overweight and obesity in children and adults during 1980-2013: a systematic analysis for the Global Burden of Disease Study . Lancet, 384(9945), 766-781

Nyoman Wahyu Meta Wulandari, Lailatul Muniroh, Triska Susila Nindya. 2016.Asupan Energi Dan Aktivitas Fisik Berhubungan Dengan Z-Score IMT/U Anak Sekolah Dasar di Daerah Perdesaan. Media Gizi Indonesia. Jilid 10 vol 1 hal 51-56

Pearson N dan Biddle SJ. 2011. Sedentary behavior and dietary intake in children, adolescents, and adults. A systematic review. Am J Prev Med. 2011 Aug;41(2):178-88. doi: 10.1016/j.amepre.2011.05.002.
Riskesdas. 2013. Departemen Kesehatan RI (Dep.Kes RI) Badan Penelitian Pengembangan Kesehatan, Riset Kesehatan Dasar (Riskesdas), Laporan Nasional 2012, Desember 2013

Suryaputra, K: Siti Rahayu Nadhiroh. 2012. Perbedaan pola makan dan aktifitas fisik antara remaja obesitas dengan non obesitas. Makara Kesehatan, VOL. 16, NO. 1, JUNI 2012: 45-50

Todd AS, Street SJ, Ziviani J.et al.,2015 Overweight and Obese Adolescent Girls: The Importance of Promoting Sensible Eating and Activity Behaviors from the Start of the Adolescent Period. Int J Environ Res Public Health. 2015 Feb; 12(2): 2306-2329. doi: [10.3390/ijerph120202306]

Tsujiguchi H, Hori D, Kambayashi Y et al., 2018. Relationship between screen time and nutrient intake in Japanese children and adolescents: a cross-sectional observational study. Environ Health Prev Med. 2018 Aug 7;23(1):34. doi: 10.1186/s12199-018-0725-0.

WHO. (2016) dalam http://www.who.int/newsroom/fact-sheets/detail/obesity-and-overweight 